\title{
How India runs its science
}

THE machinery of the government of science in India is partly a legacy of the British Raj. There is still, for example, a Department of Scientific and Industrial Research (abolished in Britain in 1963) and a National Research Development Corporation (NRDC) for the exploitation of publicly generated intellectual property; its British counterpart was first renamed the British Technology Group and then privatized, earlier this year. But the most powerful agents of Indian science are the newly created operating agencies controlling semi-industrial sectors of the technical economy such as atomic energy and space research.

There is a clutch of government ministries with technical responsibilities, of which the most obvious, but not necessarily the most influential, is the Ministry of Science and Technology. Technically, its head is the Prime Minister, who holds the cabinet portfolio for science and technology. But day-to-day business is the responsibility of a Minister of State for Science and Technology, Mr P. R. Kumaramangalam.

Kumaramangalam made something of a stir in the wake of the state assembly elections last month by writing to the prime minister (and releasing to the press) a letter complaining that their party would have done better if its leader (the prime minister) had more decisively adopted policies previously suggested. He went too far; on 2 December he resigned.

The ministry is responsible for three operating agencies - the Department for Science and Technology (DST), the DSIR and the Department of Biotechnology (called DBT). DST has the responsibility of making policy and of promoting science and technology more generally. Thus it makes grants for research projects (through a Council for Science and Engineering Research), supports professional associations and societies - including India's three rival science academies, the Indian National Science Academy (New Delhi), the Indian Academy of Sciences (Bangalore) and the National Academy of Sciences (Allahabad) - and runs projects as different as the Geological Survey of India and a scheme for the avoidance of disasters from typhoons. DST is also the chief source of support for nationally important research institutes such as the Raman Institute (Bangalore) and the Bos Institute (Calcutta).

DSIR, radically reorganized in 1985 , is a technology transfer agency (which thereby controls the NRDC) but which also contains a Council for Scientific and Induatrial Research (CSIR). That agency runs a network of 29 research laboratories as different as the Building Research Institute at Roorkie (north of Delhi) and the Centre for Cellular and Molecular Biology at Hyderabad, which is not easily distinguished from a basic research laboratory.

The Department of Biotechnology, created in 1984, is a monument to India's conviction (and in particular to that of $\mathrm{Dr}$ $\mathrm{S}$. Varadarajan, then chief secretary to the ministry) that there were important opportunities in this emergent field. The department has two laboratories of its own, including the excellent Institute of Immunology at New Delhi, but also controls a number of state-owned companies, including the Indian Vaccines Corporation Ltd (whose chairman in Varadarajan) for manufacturing viral vaccines.

In strictly money terms, other ministries may have a larger influence on India's civil science. These include the departments responsible for atomic energy, electronics, space, ocean development and chemicals and fertilizers.

Another formal source of funds for civil research is the University Grants Commission (UGC), which is technically a part of the Ministry of Human Resource Development. (Responsibility for education in India is shared between the union government and the governments of the 25 states that make up the union, but certain institutions have been singled out as being of national importance and are directly financed from the centre.)

The UGC's subventions to the more than 150 universities in India are supposed to provide academics with the infrastructure of research support. But the intended recipients say that the UGC has failed in recent years to support them adequately. The explanation has much to do with the vast scale of India's university system. There are more than a hundred universities and comparable institutions, and more than 4 million students in higher education.

Responsibility for most undergraduate education is delegated to the 4,000 or so four-year colleges scattered throughout India, many of them missionary foundations in the eighteenth and nineteenth centuries. Curricula are determined by the universities, which also provide the examinations that must be passed before graduation. Ambitious graduates usually follow a two-year masters' degree course at the university proper. The better universities maintain $\mathrm{PhD}$ programmes, but increasingly graduate students in the sciences elect to be based at one or other of India's free-standing research institutes.

Among universities, six are exceptional. There are five Indian Institutes of Technology (IITs), founded in the 1960s with assistance from well-wishing governments overseas, which have established themselves as élite engineering schools. There is also, at Bangalore, the Indian Institute of Science, founded late in the nineteenth century, which has become India's near-analogue of the Massachusetts Institute of Technology.

In principle, India thus enjoys a delicious plurality of sources of research funds. All ministries with a technical brief are able to make research contracts and grants. Successful institutions, may at any time benefit from research contracts with many different government agencies.

That is the pinnacle of succcess; other universities complain that there is just too little money for their research needs and that the procedures for finding it are not nearly as systematic as they should be.

Traditional links between ministries and research institutes they have helped to found account for a good deal of the flow of funds. Thus the outstanding Tata Institute for Fundamental Research (TIFR) at Bombay, founded by Homi Bhabha with a benefaction from the Tata family and consistently supported by the Atomic Energy Commission, is now the prime mover (and chief source of funds) for India's ambitious programme in radioastronomy (see page 620).

In ten years, much has been done to decentralize decision-making. Laboratory directors can now hope to be their own men (there appear to be no women yet) provided that they can live peacably with the scientific councils, composed of academics and potential customers, that meet about three times a year. The departments themselves are also attended by advisory councils.

What most worries working scientists is the shortage of funds. Among government agencies, defence (27.5 per cent), space (15.5 per cent) and agriculture (13.1 per cent) consume more than half the total, which is in any case a declining share of the gross domestic product. (India's research spending has fallen from its peak three or four years ago to 0.9 per cent of GDP). Some, such as C. N. R. Rao, the influential director of the Indian Institute of Science, see this as proof of the government's diminished commitment to science.

One glaring lack is that of a central advisory committee. The present prime minister has not followed his predecessors in appointing a chief scientific adviser and a powerful committee to give high-level advice. Previous arrangements of this kind were not all that successful, but especially at a time of rapid change such as this, Rao is much in need of a device for making sure that the blunt instrument of reform does not irreparably damage existing institutions, among which the universities are the most vulnerable. 